\title{
PARACANOAGEM: DESEMPENHO FíSICO EM ATLETAS DA CATEGORIA FEMININA EM
}

\section{PROVAS PARALÍMPICAS}

\section{Bárbara B.P.Gonçalves*, Edison Duarte, João P. Borin, Julia F. Marchiori, Cassiano A. Massafera}

\section{Resumo}

Conhecer a demanda nos componentes do treinamento, especificamente a questão física, é fundamental para o desempenho em competições. A Paracanoagem, modalidade recente nos jogos paralímpicos (2016), apresenta uma escassez de estudos nesses aspectos. Ela tem como objetivo que o atleta compita em uma raia claramente definida, no menor tempo possível, em uma distância de 200 ou 500 metros. Os atletas da modalidade estão agrupados em três categorias. Visando compreender o desempenho de atletas, esse trabalho aborda de forma específica a categoria caiaque feminino, das finalistas e medalhistas do Campeonato Mundial de paracanoagem de 2017. Os resultados mostram melhor desempenho na categoria KL2 em relação a KL3 e KL1.

\section{Palavras-chave:}

Canoagem, esporte aquático, desempenho esportivo.

\section{Introdução}

A paracanoagem é uma das 20 modalidades dos jogos paralímpicos, foi inserida em 2016. Ela tem como principal diferença da canoagem o agrupamento de atletas por categorias, baseada na classificação esportiva. Tal classificação faz parte do sistema de competição paralímpico. Dois tipos de embarcações competem na paracanoagem, a canoa e o caiaque. $O$ foco do presente trabalho é o caiaque, cujos atletas são classificados em três grupos: KL1, KL2 e KL3, sendo os atletas do grupo KL1 os mais comprometidos. A modalidade, por ser recente, carece de trabalhos científicos. Nesse sentido essa pesquisa tem como objetivo caracterizar o desempenho físico em atletas de paracanoagem da categoria feminina de caiaque, KL1, $\mathrm{KL} 2$ e KL3, quanto à variável velocidade, em provas paralímpicas de 200 metros.

\section{Resultados e Discussão}

A variação da velocidade média, de medalhistas e finalistas de todas as categorias ao longo da distância de 200 metros, na prova de paracanoagem, realizada no Campeonato Mundial de 2017 estão apresentadas nas Figuras 1 e 2. As três categorias evidenciam o mesmo padrão de desempenho entre as finalistas, com o primeiro momento de aceleração até os 40 metros, manutenção até os 70 metros e em seguida desaceleração. Entre as medalhistas o desempenho da velocidade se assemelha principalmente entre as categorias KL2 e KL3, enquanto a categoria KL1 apresenta velocidades mais baixas durante o percurso. Atletas, tanto finalistas quanto medalhistas de $\mathrm{KL2}$, obtiveram maior distância de aceleração e menor tempo para finalizar a prova. Vimos também que a fadiga foi iniciada após 90 metros na categoria KL1, já em KL2, na distância de 120 metros, enquanto $\mathrm{KL} 3$, as finalistas começaram a decair aos 80 metros e as medalhistas aos 100 metros. É possível relatar que a categoria KL2 apresentou maior distância em velocidade máxima, cerca de 70 metros contínuos. Verificamos que a categoria KL1 teve a menor velocidade média, por isso o maior tempo de prova, mesmo que a distância percorrida (40 metros) em velocidade máxima tenha sido igual a da categoria KL3.

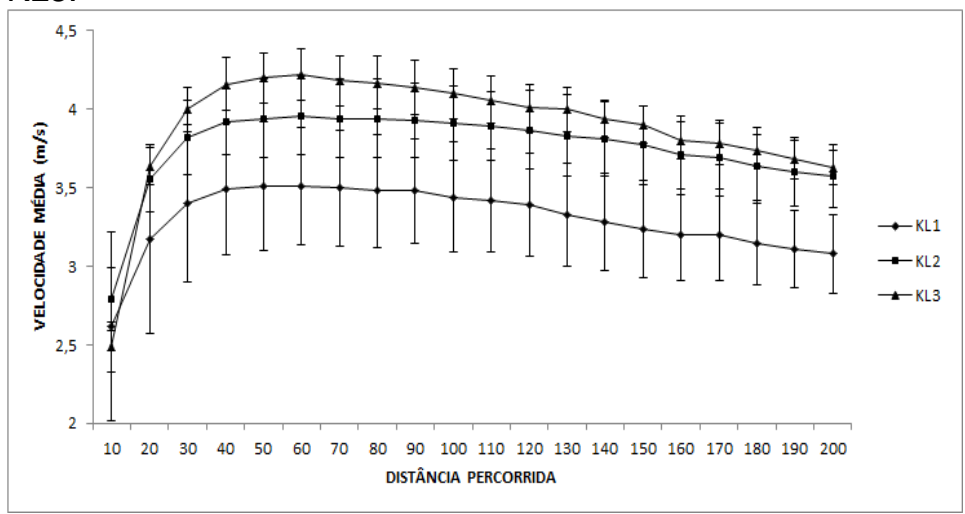

Figura 1. Velocidade média das finalistas segundo a distância percorrida nas categorias KL1, KL2 e KL3.

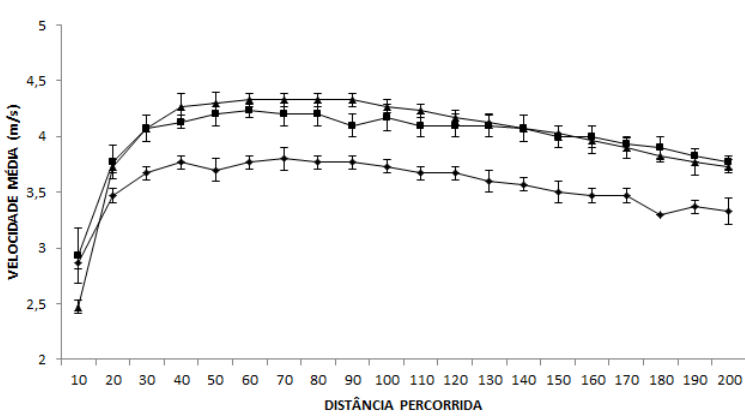

Figura 2. Velocidade média das medalhistas segundo a distância percorrida nas categorias KL1, KL2 e KL3.

\section{Conclusões}

Os resultados indicam que as atletas da categoria KL2 apresentam um metabolismo oxidativo mais desenvolvido e que o retardo da fadiga pode ser determinante para um melhor desempenho na prova.

\section{Agradecimentos}

Agradecimentos ao Programa de Iniciação Científica e Tecnológica da UNICAMP e o Conselho Nacional de Desenvolvimento Científico e tecnológico (CNPq).

ALBARELLO, Rafael Antônio. Efeito do treinamento físico/técnico sobre a composição corporal e capacidades físicas específicas de atletas da modalidade de para-canoagem. 2014. 